\title{
PERBEDAAN TINGKAT KECUKUPAN ZAT GIZI DAN RIWAYAT PEMBERIAN ASI EKSKLUSIF PADA BALITA STUNTING DAN NON STUNTING
}

\author{
Retty Anisa Damayanti' ${ }^{1}$, Lailatul Muniroh ${ }^{2}$, Farapti $^{3}$ \\ ${ }^{1}$ Program Studi S1 Ilmu Gizi, Fakultas Kesehatan Masyarakat, Universitas Airlangga, Surabaya \\ ${ }^{2}$ Departemen Gizi Kesehatan, Fakultas Kesehatan Masyarakat, Universitas Airlangga, Surabaya \\ Email: rettydamayanti@gmail.com
}

\begin{abstract}
ABSTRAK
Stunting merupakan proses akumulatif dari kurangnya asupan zat-zat gizi dalam jangka panjang. Tujuan dari penelitian ini adalah untuk menganalisis perbedaan tingkat kecukupan zat gizi dan riwayat pemberian ASI (Air Susu Ibu) eksklusif pada balita stunting dan non stunting. Penelitian ini menggunakan rancangan cross sectional pada 113 balita di Kelurahan Kejawan Putih Tambak Kecamatan Mulyorejo Kota Surabaya yang terdiri dari 27 balita stunting dan 86 balita non stunting. Besar sampel dihitung dengan perhitungan proporsional sampling. Analisis perbedaan tingkat kecukupan dan riwayat ASI eksklusif menggunakan uji Chi Square dan Exact Fisher, analisis perbedaan jumlah asupan menggunakan uji T-Sampel Bebas dan analisis besar risiko menggunakan perhitungan Odds Ratio. Hasil penelitian menunjukkan terdapat perbedaan antara balita stunting dan non stunting dalam jumlah konsumsi energi, protein, zinc, dan zat besi $(p=0,000)$. Terdapat perbedaan pula pada tingkat kecukupan energi $(p=0,000)$, protein $(p=0,042)$, zinc $(\mathrm{p}=0,000)$, dan zat besi $(\mathrm{p}=0,009)$ serta perbedaan riwayat pemberian ASI eksklusif $(\mathrm{p}=0,001)$. Balita dengan ASI non eksklusif dan balita yang memiliki tingkat konsumsi inadekuat, memiliki risiko lebih besar untuk stunting (ASI non eksklusif $=16,5$ kali, energi inadekuat $=9,5$ kali, protein inadekuat $=10,6 \mathrm{kali}$, zinc inadekuat $=7,8 \mathrm{kali}$, dan zat besi inadekuat $=3,2$ kali). Saran yang dapat diberikan, diharapkan ibu lebih meningkatkan asupan makanan pada balita terutama makanan sumber protein, zinc dan zat besi serta diharapkan ibu lebih memperhatikan pemberian ASI eksklusif dan MP ASI sesuai dengan usia balita.
\end{abstract}

Kata kunci: ASI eksklusif, balita, stunting, tingkat kecukupan zat gizi

\begin{abstract}
Stunting is an accumulative process of inadequacy number of nutrients in a long period of time. The purpose of this research was to analyse the difference of nutrients adequacy and the history of exclusive breastfeeding between stunting and non stunting toddler. This cross sectional research was done in 113 toddler who is categorized to 27 stunting toddler and 86 non stunting toddler at Kejawan Putih Tambak village, Surabaya. The number of sample was calculated with proportional sampling. To compare the nutrients adequacy and the history of exclusive breastfeeding, Chi-square test and Exact Fisher were used, to compare amount of intake, Independent T-test and Odds Ratio were calculated. As a result, there was a difference in energy, protein, zinc and iron consumption, and there was also a difference in history of exclusive breastfeeding between stunting and non-stunting toddler $(p=0.000)$, Non stunting toddler have a higher intake of energy, protein, zinc, and iron than stunting toddler. Toddler with non exclusive breastfeeding have a higher risk to be stunting than toddler with exclusive breastfeeding, and toddler who have inadequate energy, protein, zinc, and iron intake have a higher risk to be stunting than toddler with adequate energy, protein, zinc and iron intake (non-exclusive breastfeeding $=16.5$ times, inadequate energy $=4.84$ times, inadequate protein $=3.4$ times, inadequate zinc $=3.72$ times, inadequate iron $=2.36$ times). Advice that can be given is that mother should increase food intake of toddler, especially food that contain protein, zinc, and iron and mother should give also more attention to the exclusive breastfeeding and complementary feeding which is suitable with the toddler's age.
\end{abstract}

Keywords: exclusive breastfeeding, toddler, stunting, nutrient adequacy 


\section{PENDAHULUAN}

Stunting adalah gangguan pertumbuhan linier yang tidak sesuai dengan umur yang mengindikasikan kejadian jangka panjang serta merupakan dampak akumulatif dari ketidakcukupan konsumsi zat gizi, kondisi kesehatan yang buruk dan pengasuhan yang tidak memadai (Aridiyah, et al., 2015). Faktor penyebab langsung dari stunting adalah asupan makanan tidak adekuat, karakteristik balita meliputi usia, jenis kelamin, berat badan lahir dan pajang badan lahir serta adanya penyakit infeksi yang berulang. Faktor penyebab tidak langsung dari stunting adalah ketersediaan pangan, pola pengasuhan serta jangkauan dan mutu pelayanan kesehatan masyarakat (Shrimpton, 2006).

Pemenuhan gizi pada masa balita akan menentukan berbagai aspek kehidupan di masa depan. Stunting pada balita akan berdampak pada nilai sekolah yang rendah, tinggi badan yang lebih pendek, dan kurangnya kemampuan motorik pada usia sekolah serta produktivitas yang rendah dan risiko terjadinya penyakit degeneratif pada usia dewasa (Hoddinott, et al., 2013)

Kekurangan energi pada seseorang merupakan indikasi kekurangan zat gizi lain. Apabila kondisi ini dibiarkan dalam jangka waktu lama, maka akan mengakibatkan penurunan berat badan. Penurunan berat badan selanjutnya akan menyebabkan keadaan gizi kurang yang mengakibatkan terhambatnya proses pertumbuhan tinggi badan (Almatsier, 2009). Kekurangan protein menyebabkan retardasi pertumbuhan dan kematangan tulang karena protein adalah zat gizi yang essensial dalam pertumbuhan. Meskipun asupan energi cukup, apabila asupan protein kurang maka akan menghambat pertumbuhan pada balita (Oktarina dan Sudiarti, 2013). Pada defisiensi zinc, efek metabolit GH (Growth Hormone) dihambat sehingga sintesis dan sekresi IGF-1 (Insulin Like Growth Factor 1) berkurang. Berkurangnya sekresi IGF-1 menyebabkan stunting (Adriani dan Wirjatmadi, 2012). Defisiensi zat besi dapat menyebabkan gangguan pada sistem kekebalan tubuh.

Balita yang sering mengalami sakit akan berpengaruh pada pertumbuhannya karena adanya sakit akan diikuti nafsu makan menurun (Malde, et al., 2010). Pemberian ASI eksklusif dapat menurunkan risiko kejadian stunting karena ASI mengandung antibodi dan kandungan kalsium pada ASI mempunyai bioavailabilitas yang tinggi sehingga dapat diserap dengan optimal terutama dalam fungsi pembentukan tulang (Almatsier, 2009).

Berdasarkan hasil Riset Kesehatan Dasar (Riskesdas) prevalensi stunting di Indonesia adalah 36,8\% (2007), 35,6\% (2010), dan 37,2\% (2013). Di Jawa Timur, prevalensi stunting menunjukkan kecenderungan adanya penurunan yaitu $34,8 \%$ (2007), 35,8\% (2010), dan 26,1\% (2015). Untuk Kota Surabaya, prevalensi stunting tahun 2015 adalah 19,3\%. Kecamatan Mulyorejo merupakan wilayah Kota Surabaya yang prevalensi stuntingnya cenderung mengalami peningkatan yaitu $12,13 \%$ (2013), 15,6\% (2014), dan 18,7\% (2014).

Kelurahan Kejawan Putih Tambak yaitu salah satu kelurahan di wilayah Kecamatan Mulyorejo dipilih sebagai lokasi penelitian karena adanya peningkatan prevalensi stunting setiap tahun yaitu 12,7\% (2013), 14,2\% (2014), dan 20\% (2015). Prevalensi stunting di Kelurahan Kejawan Putih Tambak pada tahun 2015, lebih tinggi dari prevalensi stunting di Kota Surabaya.

Usia 2-5 tahun merupakan usia rawan terjadinya kurang gizi karena pada usia ini ASI sudah tidak diberikan sehingga zat gizi yang diterima oleh balita hanya berasal dari diet saja. Pada usia ini, balita sudah mampu memilih makanan sendiri, pendidikan gizi ibu yang kurang menyebabkan balita memilih makanan yang miskin zat gizi sehingga terjadi kondisi kekurangan zat gizi (Sunarti dan Nugrohowati, 2013).

Cakupan pemberian ASI eksklusif di Kelurahan Kejawan Putih Tambak paling rendah dibandingkan kelurahan lainnya di Kecamatan Mulyorejo yaitu 60\% (2013), 76\% (2014) dan $80 \%$ (2015), serta prevalensi stunting yang paling tinggi yang mengindikasikan adanya kondisi kekurangan gizi kronis. Oleh karena itu, tujuan dari penelitian ini adalah menganalisis perbedaan, tingkat kecukupan zat gizi terutama zat gizi yang berhubungan dengan pertumbuhan linear yaitu protein, zinc, dan zat besi serta perbedaan riwayat pemberian ASI eksklusif antara balita stunting dan 
non stunting usia 2-5 tahun di Kelurahan Kejawan Putih Tambak Surabaya

\section{METODE}

Jenis penelitian ini merupakan penelitian observasional dengan menggunakan desain penelitian cross sectional. Penelitian dilaksanakan pada bulan Februari-Mei tahun 2016 di Kelurahan Kejawan Putih Tambak Kecamatan Mulyorejo, Kota Surabaya.

Sampel penelitian adalah 113 balita berusia 2-5 tahun yang terdiri dari 27 balita stunting dan 86 balita non stunting. Besar sampel masingmasing kelompok ditentukan dengan perhitungan proportional sampling dengan rumus $\mathrm{n} / \mathrm{N} \times \mathrm{T}$ ( $\mathrm{n}=$ besar sampel masing-masing kelompok, $\mathrm{N}=$ besar populasi, $\mathrm{T}=$ besar sampel total) (Amanda, 2014).

Variabel dalam penelitian ini adalah karakteristik balita (usia, jenis kelamin, berat badan lahir, dan panjang badan lahir), tingkat kecukupan (energi, protein, zinc, dan zat besi), jumlah konsumsi (energi, protein, zinc dan zat besi), pola asuh (riwayat pemberian ASI eksklusif dan Makanan Pendamping ASI/MP ASI) serta status gizi Tinggi Badan menurut Umur (TB/U).

Berat badan lahir dikategorikan menjadi BBLR dan normal sedangkan panjang badan lahir dikategorikan pendek dan normal. Balita masuk dalam kategori BBLR (Berat Badan Lahir Rendah) jika memiliki berat badan lahir kurang dari 2500 gram sedangkan kategori panjang badan lahir kategori pendek jika balita memiliki panjang badan lahir kurang dari $48 \mathrm{~cm}$ (Ngaisyah, 2016)

Tingkat kecukupan energi dan zat gizi dikategorikan menjadi adekuat dan inadekuat. Menurut Gibson (2005), tingkat kecukupan energi, protein, dan zinc dikatakan adekuat jika $\geq 77 \%$ AKG (Angka Kecukupan Gizi). AKG energi untuk balita usia 2-3 tahun adalah $1125 \mathrm{kkal} / \mathrm{hari}$, AKG protein $26 \mathrm{gr} / \mathrm{hari}$ dan $\mathrm{AKG}$ zat besi $8 \mathrm{mg} / \mathrm{hari}$. Untuk balita usia 4-5 tahun, AKG energi adalah 1600 kalori/hari. AKG protein $35 \mathrm{gr} / \mathrm{hari}$ dan AKG zat besi $9 \mathrm{mg} /$ hari. Untuk tingkat kecukupan zinc
Tabel 1. Besar Sampel masing-masing Kelompok

\begin{tabular}{lcc}
\hline \multicolumn{1}{c}{ Kelompok } & Besar Populasi & Besar Sampel \\
\hline Stunting & 45 & $45 / 186 \times 113=27$ \\
Non stunting & 141 & $141 / 186 \times 113=86$ \\
\hline Total & 186 & 113 \\
\hline
\end{tabular}

dihitung dengan $\mathrm{AKG}$ yang dikonversikan dengan EAR (Estimated Average Requirements). AKG zinc balita usia 2-3 tahun adalah $4 \mathrm{mg}$ /hari dengan $E A R$ 1,2 , setelah dikonversikan menjadi $3,3 \mathrm{mg} /$ hari. AKG zinc balita usia 4-5 tahun adalah $45 \mathrm{mg}$ /hari dengan EAR 1,2, setelah dikonversikan menjadi 4,16 mg/hari. Konversi dilakukan dengan cara membagi angka AKG dengan angka $E A R$. Tingkat kecukupan zinc masuk dalam kategori adekuat jika $\geq 3,3 \mathrm{mg}$ pada balita usia $2-3$ tahun dan $\geq 4,16 \mathrm{mg}$ pada balita usia 4-5 tahun.

Peneliti melakukan pengukuran antropometri dengan indikator $\mathrm{TB} / \mathrm{U}$. Balita dengan z-score $<-2 \mathrm{SD}$ termasuk dalam kelompok stunting sedangkan balita dengan $\mathrm{z}$-score $\geq-2 \mathrm{SD}$ termasuk dalam kelompok non stunting, $\mathrm{z}$-score dihitung dengan menggunakan software WHOAnthro. Selanjutnya, ibu diwawancarai dengan menggunakan kuisioner dan form food recall $2 \times 24$ hours.

Untuk menganalisis perbedaan tingkat kecukupan energi, protein, zinc, dan zat besi serta riwayat pemberian ASI antara balita stunting dan non stunting menggunakan uji Chi Square $2 \times 2$ karena skala data adalah nominal, jika tidak memenuhi syarat maka digunakan uji Exact Fisher (Pahlevi, 2012). Untuk menganalisis perbedaan jumlah konsumsi energi, protein, zinc, dan zat besi antara balita stunting dan non stunting menggunakan Uji-T Sampel bebas karena skala data adalah rasio, jika data tidak berdistribusi normal menggunakan uji Mann Whitney, dan untuk uji normalitas menggunakan uji KolmogorovSmirnov (Suiraoka, 2011). Analisis besar risiko menggunakan perhitungan OR (Odds Ratio) karena perhitungan OR digunakan untuk penelitian dengan desain cross sectional (Lestari, et al., 2014). 


\section{HASIL DAN PEMBAHASAN}

\section{Karakteristik Balita}

Karakteristik balita merupakan faktor penyebab langsung dari kejadian stunting. Karakteristik balita yang diteliti dalam penelitian ini adalah usia, jenis kelamin, berat badan lahir dan panjang badan lahir.

Berdasarkan tabel 2, pada balita usia 24-59 bulan Kelurahan Kejawan Putih Tambak Surabaya, balita stunting paling banyak ditemukan pada kelompok usia 36-47 bulan yaitu sebesar 31,4\%. Hal ini sejalan dengan penelitian Bahmat (2015) di Nusa Tenggara yang menyimpulkan bahwa balita stunting paling banyak pada usia $36-47$ bulan. Hal tersebut disebabkan karena mulai tahun kedua kehidupan, laju pertumbuhan melambat dan terjadi perubahan bentuk tubuh balita menjadi lebih berotot.

Stunting lebih banyak terjadi pada balita berjenis kelamin laki-laki yaitu $25,0 \%$, sedang pada balita perempuan sebesar $22,6 \%$. Hal ini sesuai dengan penelitian Roscha, et al. (2013) yang menganalisis data Riskesdas menyatakan bahwa balita stunting lebih banyak berjenis kelamin lakilaki (39,5\%).

Lebih banyaknya prevalensi stunting pada balita laki-laki disebabkan karena laki-laki lebih berisiko untuk mengalami kekurangan gizi akibat lebih banyaknya kebutuhan energi protein pada laki-laki. Jenis kelamin menentukan besar kecilnya kebutuhan energi protein seseorang (Bahmat, 2010).
Balita BBLR cenderung mengalami stunting yaitu sebesar $83,3 \%$. Berdasarkan nilai Odds Ratio dapat dinyatakan bahwa balita dengan riwayat BBLR memiliki risiko stunting 19,3 kali lebih besar dibandingkan dengan balita dengan riwayat berat badan lahir normal. Hal ini sejalan dengan penelitian Adel (2014) pada balita usia 1-2 tahun di Libya yang menyimpulkan bahwa berat badan lahir rendah mempengaruhi kejadian stunting pada anak usia $1-2$ tahun $(\mathrm{p}<0,05, \mathrm{OR}=1,58)$. Balita BBLR lebih berisiko untuk menjadi stunting karena balita BBLR memiliki kerentanan yang lebih tinggi terhadap penyakit infeksi, seperti diare dan infeksi saluran pernafasan bawah serta peningkatan risiko komplikasi termasuk sleep apnea, ikterus, anemia, gangguan paru-paru kronis, kelelahan, dan hilangnya nafsu makan dibandingkan dengan anak-anak dengan berat badan lahir yang normal sehingga mengakibatkan pertumbuhan fisik yang tidak optimal (Rahman, et al., 2016).

Proporsi balita dengan riwayat panjang badan lahir pendek lebih banyak pada kelompok stunting yaitu sebesar $43,8 \%$ dan pada anak yang lahir dengan panjang badan normal sebesar $20,6 \%$. Balita dengan riwayat panjang badan lahir pendek memiliki risiko stunting 2,9 kali lebih besar dibandingkan dengan balita dengan riwayat panjang badan lahir normal. Hal ini sejalan dengan penelitian Meilyasari dan Isnawati (2014) yang menyimpulkan bahwa panjang badan lahir pendek memiliki pengaruh paling besar dengan kejadian stunting. Menurut Meilyasari dan Isnawati (2014), balita dengan riwayat panjang badan lahir

Tabel 2. Karakteristik Balita

\begin{tabular}{|c|c|c|c|c|c|c|c|}
\hline \multirow{2}{*}{ Variabel } & \multicolumn{2}{|c|}{ Stunting } & \multicolumn{2}{|c|}{ Non stunting } & \multicolumn{2}{|c|}{ Total } & \multirow{2}{*}{ OR } \\
\hline & $\mathbf{n}$ & $\%$ & $\mathbf{n}$ & $\%$ & $\mathbf{N}$ & $\%$ & \\
\hline \multicolumn{8}{|l|}{ Usia } \\
\hline $24-35$ & 8 & 19,0 & 34 & 81,0 & 42 & 100 & \\
\hline $36-47$ & 11 & 31,4 & 24 & 68,6 & 35 & 100 & 1,9 \\
\hline $48-59$ & 8 & 22,2 & 28 & 77,8 & 36 & 100 & \\
\hline \multicolumn{8}{|l|}{ Jenis Kelamin } \\
\hline Laki-laki & 15 & 25,0 & 45 & 75,0 & 60 & 100 & 1,1 \\
\hline Perempuan & 12 & 22,6 & 41 & 77,4 & 53 & 100 & \\
\hline \multicolumn{8}{|l|}{ Berat Badan Lahir } \\
\hline BBLR & 5 & 83,3 & 1 & 16,7 & 6 & 100 & 19,3 \\
\hline Normal & 22 & 20,6 & 85 & 79,4 & 107 & 100 & \\
\hline \multicolumn{8}{|c|}{ Panjang Badan Lahir } \\
\hline Pendek & 7 & 43,8 & 9 & 56,2 & 16 & 100 & 2,9 \\
\hline Normal & 20 & 20,6 & 77 & 79,4 & 97 & 100 & \\
\hline
\end{tabular}


pendek merupakan indikasi terjadinya kekurangan pemenuhan zat gizi ibu selama kehamilan dan indikasi adanya gangguan pertumbuhan dalam uterus yang menyebabkan pertumbuhan linear menjadi tidak optimal. Kekurangan gizi sejak dalam kandungan berpengaruh terhadap organ dan pertumbuhan janin. Bayi yang mengalami kekurangan gizi selama masa kehamilan masih dapat diperbaiki dengan asupan yang baik sehingga dapat melakukan tumbuh kejar sesuai dengan perkembangannya. Namun, apabila intervensinya terlambat dapat mengalami gagal tumbuh.

\section{Tingkat Kecukupan Energi dan Zat Gizi}

Asupan makan yang tidak adekuat merupakan penyebab langsung terjadinya stunting pada balita. Kurangnya asupan energi dan protein menjadi penyebab gagal tumbuh telah banyak diketahui. Kurangnya beberapa mikronutrien juga berpengaruh terhadap terjadinya retardasi pertumbuhan linear. Kekurangan mikronutrien dapat terjadi karena rendahnya asupan bahan makanan sumber mikronutrien tersebut dalam konsumsi balita sehari-hari serta disebabkan karena bioavailabilitas yang rendah (Mikhail, et al., 2013).

Asupan makanan yang diteliti dalam penelitian ini terdiri dari tingkat kecukupan serta jumlah konsumsi energi dan zat gizi lainnya yaitu protein, zinc, dan zat besi. Hasil penelitian menunjukkan bahwa proporsi balita yang memiliki tingkat kecukupan energi, protein, zinc, dan zat besi inadekuat lebih banyak pada kelompok stunting dibandingkan kelompok non stunting. Hasil penelitian juga menunjukkan bahwa tingkat asupan energi, protein, zinc dan zat besi yang inadekuat akan meningkatkan risiko terjadinya stunting pada balita.

Hasil penelitian menunjukkan bahwa proporsi balita yang memiliki tingkat kecukupan energi inadekuat lebih banyak pada kelompok stunting $(54,5 \%)$ dan balita yang memiliki tingkat kecukupan energi inadekuat memiliki risiko stunting 9,5 kali lebih besar dibandingkan dengan balita yang memiliki tingkat kecukupan energi adekuat. Hal ini sejalan dengan penelitian Oktarina dan Sudiarti (2013) yang menyebutkan bahwa balita dengan asupan energi rendah mempunyai risiko 1,28 kali lebih besar untuk mengalami stunting dibandingkan dengan balita yang memiliki tingkat kecukupan energi cukup.

Proporsi balita yang memiliki tingkat kecukupan protein inadekuat lebih banyak pada kelompok stunting (75\%) dan dapat diketahui pula bahwa balita yang memiliki tingkat kecukupan protein inadekuat memiliki risiko stunting 10,6 kali lebih besar dibandingkan dengan balita yang memiliki tingkat kecukupan protein adekuat. Penelitian oleh Nungo (2012) pada balita usia 1-5 tahun di Kenya dan Hidayati, et al. (2010) pada balita usia 1-3 tahun di Surakarta menyimpulkan bahwa balita yang memiliki tingkat kecukupan protein tidak adekuat mempunyai risiko 3,46 kali akan menjadi stunting dibandingkan dengan balita dengan asupan protein adekuat.

Kecukupan protein hanya bisa terpenuhi jika asupan energi tercukupi. Apabila asupan energi kurang, asupan protein akan digunakan untuk

Tabel 3. Perbedaan Tingkat Kecukupan Zat Gizi

\begin{tabular}{|c|c|c|c|c|c|c|}
\hline \multirow{2}{*}{ Variabel } & \multicolumn{2}{|c|}{ Stunting } & \multicolumn{2}{|c|}{ Non Stunting } & \multirow{2}{*}{ P-value } & \multirow{2}{*}{ OR } \\
\hline & $\mathbf{n}$ & $\%$ & $\mathbf{n}$ & $\%$ & & \\
\hline \multicolumn{7}{|c|}{ Tingkat kecukupan energi } \\
\hline Inadekuat & 18 & 54,5 & 15 & 45,5 & 0,000 & 9,5 \\
\hline Adekuat & 9 & 11,2 & 71 & 88,8 & & \\
\hline \multicolumn{7}{|c|}{ Tingkat kecukupan protein } \\
\hline Inadekuat & 3 & 75,0 & 1 & 25,0 & 0,042 & 10,6 \\
\hline Adekuat & 24 & 22,0 & 85 & 78,0 & & \\
\hline \multicolumn{7}{|c|}{ Tingkat kecukupan zinc } \\
\hline Inadekuat & 12 & 60,0 & 8 & 40,0 & 0,000 & 7,8 \\
\hline Adekuat & 15 & 16,1 & 78 & 83,9 & & \\
\hline \multicolumn{7}{|c|}{ Tingkat kecukupan zat besi } \\
\hline Inadekuat & 16 & 37,2 & 27 & 62,8 & 0,009 & 3,2 \\
\hline Adekuat & 11 & 15,7 & 59 & 84,3 & & \\
\hline
\end{tabular}


memenuhi kebutuhan energi. Pertumbuhan balita membutuhkan tambahan protein. Ketidakcukupan asupan protein dapat menghambat laju pertumbuhan (Adriani dan Wirjatmadi, 2012).

Pertumbuhan pada balita akan meningkatkan jumlah total protein dalam tubuh sehingga membutuhkan protein lebih besar daripada orang dewasa. Protein memegang peranan esensial dalam mengangkut zat-zat gizi dari saluran cerna. Kekurangan protein akan mengganggu berbagai proses dalam tubuh dan menurunkan daya tahan tubuh terhadap penyakit (Almatsier, 2009).

Kuantitas dan kualitas protein yang dikonsumsi mempengaruhi kadar plasma Insulin Like Growth Factor I (IGF-I) yang merupakan mediator hormon pertumbuhan. Protein juga mempengaruhi pertumbuhan matriks tulang yang memiliki peran penting dalam pembentukan tulang (Mikhail, et al., 2013).

Proporsi balita yang memiliki tingkat kecukupan zinc inadekuat lebih banyak pada kelompok stunting (60\%) dan balita yang memiliki tingkat kecukupan zinc inadekuat memiliki risiko stunting 7,8 kali lebih besar dibandingkan dengan balita yang memiliki tingkat kecukupan zinc adekuat. Hal ini sejalan dengan penelitian Gibson, et al. (2007) yang menyimpulkan bahwa defisiensi zinc menghambat pertumbuhan linear pada anak usia 6-13 tahun di NE Thailand. Arsenault, et al. (2008) pada penelitiannya juga menyimpulkan bahwa balita yang menerima suplementasi zinc memiliki pertumbuhan yang lebih baik karena konsumsi zinc dapat menstimulasi nafsu makan, meningkatkan asupan energi serta meningkatkan massa bebas lemak pada tubuh.

Zinc berfungsi dalam pembentukan antibodi, berperan dalam fungsi indera pengecap dan hormon pertumbuhan. Kekurangan zinc dapat mengakibatkan hipogeusia atau penurunan nafsu makan dan hiposmia atau kehilangan indra bau (Almatsier, 2009). Zinc berperan dalam proses pertumbuhan dan perkembangan pada balita, zinc membantu melawan infeksi dan membantu kerja hormon pertumbuhan. Pada defisiensi zinc, kerja dari hormon pertumbuhan akan dihambat (Aridiyah, et al., 2015).

Proporsi balita yang memiliki tingkat kecukupan zat besi inadekuat lebih banyak pada kelompok stunting $(37,2 \%)$ dan balita yang memiliki tingkat kecukupan zat besi inadekuat memiliki risiko stunting 3,2 kali lebih besar dibandingkan dengan balita yang memiliki tingkat kecukupan zat besi adekuat.

Penelitian Hidayati, et al. (2010) menyimpulkan bahwa asupan zat besi inadekuat meningkatkan risiko stunting 3,46 kali lebih besar pada balita. Balita dengan defisiensi zat besi akan mengalami penurunan terhadap kekebalan tubuh sehingga memiliki risiko lebih besar untuk mengalami penyakit terutama penyakit infeksi. Adanya penyakit infeksi dan anoreksia akan menghambat pertumbuhan linear karena menurunkan intake makanan, mengganggu absorpsi zat gizi, dan menyebabkan hilangnya zat gizi (Mikhail, et al., 2013). Berdasarkan hasil penelitian diketahui bahwa balita non stunting memiliki jumlah rata-rata konsumsi energi, protein, zinc dan zat besi yang lebih tinggi dibandingkan dengan balita stunting.

Berdasarkan uji statistik juga diketahui ada perbedaan jumlah konsumsi energi, protein, zink, dan zat besi antara balita stunting dan non stunting di Kelurahan Kejawan Putih Tambak Surabaya. Hal ini sejalan dengan penelitian yang dilakukan oleh Suiraoka, et al. (2011) pada balita usia 2-5 tahun di Denpasar yang menyimpulkan bahwa ada perbedaan bermakna jumlah rata-rata konsumsi energi dan protein per hari pada kelompok balita

Tabel 4. Perbedaan Jumlah Konsumsi Zat Gizi

\begin{tabular}{lccc}
\hline \multirow{1}{*}{ Variabel } & \multicolumn{2}{c}{ Kelompok } & \multirow{2}{*}{$\boldsymbol{P}$-value } \\
\cline { 2 - 3 } & Stunting & Non Stunting & \\
\cline { 2 - 3 } & mean \pm SD & $1.116,2 \pm 196,4$ & 0,000 \\
Energi (kkal) & $847,6 \pm 224,12$ & $51,9 \pm 11,0$ & 0,000 \\
Protein (gr) & $37,8 \pm 14,6$ & $5,7 \pm 1,7$ & 0,000 \\
Zinc (mg) & $3,8 \pm 1,6$ & $8,5 \pm 3,5$ & 0,000 \\
Zat besi (mg) & $5,4 \pm 3,5$ & & \\
\hline
\end{tabular}


normal dan kelompok balita stunting dengan jumlah rata-rata konsumsi energi dan protein balita non stunting lebih tinggi dibandingkan dengan balita stunting. Penelitian ini juga sejalan dengan penelitian Hidayati, et al. (2010) pada balita usia 1-3 tahun di wilayah perkotaan kumuh Surakarta yang menyimpulkan bahwa kekurangan asupan zinc dan zat besi pada balita menyebabkan balita mempunyai risiko lebih besar terhadap kejadian stunting.

\section{Riwayat Pemberian ASI dan MP ASI}

Pola asuh merupakan faktor tidak langsung yang mempengaruhi terjadinya stunting pada balita. Pola asuh yang diteliti dalam penelitian ini adalah riwayat pemberian ASI eksklusif dan riwayat usia pertama pemberian MP ASI. Pemberian ASI dikatakan eksklusif jika balita hanya mendapatkan ASI saja tanpa tambahan makanan atau minuman apapun mulai dari lahir sampai usia 6 bulan (Zogara, et al., 2014).

Pada penelitian, diketahui ada 16 balita yang tidak pernah mendapatkan ASI dengan alasan ASI tidak bisa keluar dan ibu sakit pada saat melahirkan. Proporsi balita yang tidak mendapatkan ASI non eksklusif lebih banyak pada kelompok stunting. Berdasarkan uji statistik diketahui bahwa ada perbedaan riwayat pemberian ASI eksklusif antara balita stunting dengan balita non stunting $(\mathrm{p}=0,001)$. Balita dengan riwayat mendapatkan ASI non eksklusif memiliki risiko stunting 16,5 kali lebih besar dibandingkan balita dengan riwayat mendapatkan ASI eksklusif. Hal ini sejalan dengan penelitian Lestari, et al. (2014) di Aceh yang menyimpulkan bahwa bayi dengan ASI non eksklusif memiliki risiko lebih besar untuk mengalami stunting $(\mathrm{OR}=6,54)$.

Balita dengan riwayat ASI non eksklusif lebih berisiko untuk stunting karena hal ini berhubungan dengan kejadian penyakit infeksi seperti diare yang lebih banyak terjadi pada bayi dibawah 6 bulan yang diberikan makanan selain ASI. Adanya penyakit infeksi menyebabkan menurunnya nafsu makan, menurunnya penyerapan zat gizi dan peningkatan katabolisme sehingga zat gizi tidak mencukupi untuk pertumbuhan (Lestari, et al., 2014).

Sebagian besar balita memiliki riwayat mendapatkan MP ASI terlalu dini ( $<6$ bulan). Proporsi balita yang mendapatkan MP ASI dini lebih besar pada kelompok balita stunting. Berdasarkan uji statistik diketahui bahwa ada perbedaan usia pemberian MP ASI balita stunting dengan balita non stunting $(\mathrm{p}=0,000)$. Balita dengan riwayat mendapatkan MP ASI dini memiliki risiko stunting 9,9 kali lebih besar dibandingkan dengan balita dengan riwayat mendapatkan MP ASI non dini. Hal ini sesuai dengan penelitian Aridiyah, et al. (2015) pada balita di Jember yang menyimpulkan bahwa pemberian ASI eksklusif dan usia pertama pemberian MP ASI merupakan faktor yang berhubungan dengan kejadian stunting pada balita. Pemberian makanan terlalu dini dapat mengganggu pemberian ASI eksklusif serta menjadikan bayi rentan terhadap penyakit karena enzim pencernaan pada bayi belum mencapai jumlah yang cukup untuk mencerna makanan kasar sampai usia 6 bulan. Kebersihan yang kurang pada pemberian MP ASI juga berisiko mengakibatkan diare (Zogara, et al., 2014).

\section{KESIMPULAN DAN SARAN}

Kesimpulan yang bisa diambil dari penelitian ini adalah balita dengan riwayat BBLR dan/ panjang badan lahir pendek memiliki risiko lebih besar untuk mengalami stunting. Terdapat perbedaan tingkat kecukupan energi, protein, zinc,

Tabel 5. Riwayat Pemberian ASI Eksklusif dan MP ASI

\begin{tabular}{|c|c|c|c|c|c|c|c|c|}
\hline \multirow{2}{*}{ Variabel } & \multicolumn{2}{|c|}{ Stunting } & \multicolumn{2}{|c|}{ Non stunting } & \multicolumn{2}{|c|}{ Total } & \multirow{2}{*}{ P-value } & \multirow{2}{*}{ OR } \\
\hline & $\mathbf{n}$ & $\%$ & $\mathbf{n}$ & $\%$ & $\mathbf{N}$ & $\%$ & & \\
\hline \multicolumn{9}{|l|}{ Riwayat Pemberian ASI } \\
\hline Non Eksklusif & 17 & 29,8 & 40 & 70,2 & 57 & 100 & \multirow[t]{2}{*}{0,001} & \multirow[t]{2}{*}{16,5} \\
\hline Eksklusif & 1 & 2,5 & 39 & 97,5 & 40 & 100 & & \\
\hline \multicolumn{9}{|c|}{ Usia Pemberian MP ASI (bulan) } \\
\hline$<6$ & 25 & 34,2 & 48 & 65,8 & 73 & 100 & \multirow{2}{*}{0,000} & \multirow{2}{*}{9,9} \\
\hline$\geq 6$ & 2 & 5 & 38 & 95 & 40 & 100 & & \\
\hline
\end{tabular}


dan zat besi pada balita stunting dan non stunting di Kelurahan Kejawan Putih Tambak Surabaya di mana balita yang memiliki tingkat kecukupan energi, protein, zinc, dan zat besi inadekuat memiliki risiko lebih besar untuk stunting (energi inadekuat $=9,5 \mathrm{kali}$, protein inadekuat $=10.6 \mathrm{kali}$, zinc inadekuat $=7,8$ kali, zat besi inadekuat $=3,2$ kali). Terdapat perbedaan riwayat pemberian ASI pada balita stunting dan non stunting dimana balita yang mendapatkan ASI non eksklusif memiliki risiko 16,5 kali lebih besar untuk stunting.

Saran yang dapat diberikan, diharapkan ibu lebih meningkatkan asupan makanan terutama makanan sumber zat gizi yang memiliki keterkaitan dengan pertumbuhan linear pada balita yaitu makanan sumber protein, zinc, dan zat besi serta diharapkan ibu lebih memperhatikan pemberian ASI eksklusif dan MP ASI sesuai dengan usia balita.

\section{DAFTAR PUSTAKA}

Adriani, M. dan Wirjatmadi, B. (2012). Gizi dan Kesehatan Balita. Jakarta: Kencana Prenada Media Group.

Adel, E.T., Marie-Francoise, R., Salaheddin, M.M., Najeeb, E., Ahmed, M. A., Ibrahim, B., Gerard, L. (2008). Nutritional Status of Under-Five Children in Libya:A National Population-Based Survey. Libyan Journal of Medicine, 3(1), 13-19. Diakses dari http:www.ncbi.nlm.nih. gov/pmc/articles/PMC3074324/

Almatsier, S. (2009). Prinsip Dasar Ilmu Gizi. Jakarta: Gramedia Pustaka Utama.

Amanda, A. (2014). Hubungan Asupan Zat Gizi (Energi, Protein, Besi dan Seng), Stunting dan Stimulasi Psikososial dengan Status Motorik Anak Usia 3-6 tahun di PAUD Wilayah Binaan Puskesmas Kecamatan Kebayoran Lama Tahun 2014. (Skripsi, Universitas Islam Negeri Syarif Hidayatullah, Jakarta). Diakses dari http://repository.uinjkt.ac.id/dspace/ bitstream/123456789/27270/1/AMEILIA\%20 AMANDA-FKIK.pdf

Aridiyah, F.O., Rohmawati, N., Ririanty, M. (2015). Faktor-faktor yang Memengaruhi Kejadian Stunting pada Anak Balita di Wilayah Pedesaan dan Perkotaan. E-Jurnal Pustaka Kesehatan, 3,1. Diakses dari jurnal.unej.ac.id/index.php/ JPK/article/download/2520/2029
Arsenault, J.E., Roman D.L., a, Penny, M., Loan M.D., Brown K.H. (2008). Additional Zinc Delivered in a Liquid Supplement, but Not in a Fortified Porridge, Increased Fat-Free Mass Accrual among Young Peruvian Children with Mild-to-Moderate Stunting. J. Nutr, 138, 108-114. Diakses dari www.ncbi.nlm.nih.gov/ pubmed/ 18156412

Bahmat, D. (2015). Hubungan Asupan Seng, Vitamin A, Zat Besi Pada Balita (24-59 Bulan) dan Kejadian Stunting di Kepulauan Nusa Tenggara (Riskesdas 2010). (Skripsi, Universitas Esa Unggul, Jakarta). Diakses dari http://digilib.esaunggul.ac.id/hubunganasupan-seng-zn-vitamin-a-zat-besi-fe-padabalita-2459-bulan-dan-kejadian-stunting-dikepulauan-nusa-tenggara-riskesdas-2010-5792. html.

Gibson, R.S. (2005). Principle of Nutritional and Assessment. New York: Oxford University Press.

Gibson R.S., Manger M.S., Krittaphol, W., Pongcharoen T., Gowachirapant S., Bailey K. B., Winichagoon, P. (2007). Does Zinc Deficiency Play a Role in Stunting Among Primary School Children in NE Thailand? British Journal of Nutrition, 97, 167-175. Diakses dari www.ncbi. nlm.nih. gov/pubmed/ 17217573.

Hidayati, L., Hadi, H., Kumara, A. (2010). Kekurangan Energi dan Zat Gizi Merupakan Faktor Risiko Kejadian Stunted pada Anak Usia 1-3 Tahun yang tinggal di Wilayah Kumuh Perkotaan Surakarta. Jurnal Kesehatan, 3(1), 89-104. Diakses dari https://publikasiilmiah. ums.ac.id/bitstream/handle/11617/2315/10.\%20 LISTYANI\%20H.pdf?sequence $=1$

Hoddinott, J., Behrman, J.R., Maluccio, J.A., Melgar, P., Quisumbing, A., Zea, M. R., Stein, A. D., Yount, K. M., Martorell, R. (2013). Adult Consequences of Growth Failure in Early Childhood. Am J Clin Nutr, 98, 1170-1178. Diakses dari http://ajen. nutrition.org/content/98 /5/1170.full

Lestari, W., Margawati, A., Rahfiludin, M. (2014). Faktor Risiko Stunting pada Anak Umur 6-24 Bulan di Kecamatan Penanggalan Kota Subussalam Provinsi Aceh. Jurnal Gizi Indonesia, 3(1), 37-45. Diakses dari http:// ejournal. undip.ac.id/index.php/jgi/article/ download/8752/7081

Malde, M. K., Zerihun, L., Bjorvatn K., Julshamn K. (2010). Intake of Iron, Zinc and Iodine in 28 Ethiopian Children Living in Wonji Shoa 
Sugar Estate, Assessed by Duplicate Portion Technique. Academic Journals, 5(8), 730-736. Tersedia http://www.academicjournals.org/ SRE

Meilyasari, F., dan Isnawati, M. (2014). Faktor Risiko Kejadian Stunting pada Balita Usia 12 Bulan di Desa Purwokerto Kecamatan Patebon, Kabupaten Kendal. Journal of Nutrition College, 3, 2, 16-25. Diakses dari http://ejournal-s1. undip.ac.id/ index.php/jnc/article/view/5437

Mikhail, W.Z.A., Sobhy, H.M., El-Sayed, H.H., Khairy, S.A., Abu Salem, H.Y.H., Samy, M.A. (2013). Effect of Nutritional Status on Growth Pattern of Stunted Preschool Children in Egypt. Academic Journal of Nutrition, 2(1), 1-9, doi: 10.5829/idosi.ajn.2013.2.1.7466. Diakses dari www.idosi.org/ ajn/2(1)13/1.pdf

Mwaniki, E.W., Makokha, A.N. (2013). Nutrition Status and Associated Factors Among Children in Public Primary Schools in Dagoretti, Nairobi, Kenya. African Health Sciences, 13(1), 39-46, doi:10.4314/ ahs.v13i1.6. Diakses dari http:// www.ncbi.nlm.nih.gov/pubmed/23658566

Nungo, R., Okoth, M., Samuel, K. (2012). Nutrition Status of Children Under Five Years in Cassava Consuming Communitiesin Nambale, Busia of Western Kenya. Journal Food and Nutrition Science, 3, 796-801. Diakses dari agris.fao.org/ agris-search/search. do? recordID $=$ DJ2012078217

Ngaisyah, D. (2016). Hubungan Riwayat Lahir Stunting dan BBLR dengan Status Gizi Anak Balita Usia 1-3 Tahun di Potorono, Bantul Yogyakarta. Jurnal Medika Respati, 11(2), 51-61. Diakses dari http://journal. respati.ac.id/ index.php/medika/article/viewFile/488/419

Oktarina, Z., dan Sudiarti, T. (2013). Faktor Risiko Stunting pada Balita (24-59 bulan) di Sumatera. Jurnal Gizi dan Pangan, 8(3), 175-180. Diakses dari http://journal.ipb. ac.id/index.php/ jgizipangan/article/view/7977

Pahlevi, A.E. (2012). Determinan Status Gizi Pada Siswa Sekolah Dasar. Jurnal Kesehatan Masyarakat, 7(2), 122-126. Diakses dari http:// journal. unnes.ac.id/index.php/kemas
Rahman, M.S., Howlader, T., Masud, M.S., Rahman, M.L. (2016). Association of Low-Birth Weight with Malnutrition in Children under Five Years in Bangladesh: Do Mother's Education, Socio-Economic Status, and Birth Interval Matter?. Journal Plos One, 11(6), doi:10.1371. Diakses dari http://dx.doi.org/10.1371/ journal. pone. 0157814 .

Roscha, B.C., Putri, B.S.K., Putri, I.Y.S. (2013). Determinan Status Gizi Pendek Anak Balita dengan Riwayat Berat Badan Lahir Rendah (BBLR) di Indonesia (Analisis Data Riskesdas 2007-2010). Jurnal Ekologi Kesehatan, 12(3) 195-205. Diakses dari http://ejournal. litbang.depkes.go.id/index.php/jek/article/ download/3866/3716.

Sunarti, Nugrowati, A.K (2014). Korelasi Status Gizi, Asupan Zat Besi dengan Kadar Feritin pada Anak usai 2-5 Tahun di Kelurahan Semanggi Surakarta. Jurnal Kesehatan Masyarakat, 8(1), 11-18. Diakses dari http:// journal.uad.ac.id/index.php/KesMas/article/ download/1037/768.

Suiraoka, I., Kusumajaya. A., Larasati, N. (2011). Perbedaan Konsumsi Energi, Protein, Vitamin A dan Frekuensi Sakit karena Infeksi pada Anak Balita Status Gizi Pendek dan Normal di Wilayah Kerja Pusesmas Kanasem I. Jurnal Ilmu Gizi, 2, 74-82. Diakses dari poltekkes-denpasar.ac.id/ files/JIG/V2N1/Suiraoka.pdf

Shrimpton, R., Victora C. G., de Onis M., Lima R.C., Blossner M., Clugston, G., (2006). Worldwide Timing of Growth Faltering: Implications for Nutritional Interventions. $A A P$ Journal Pediatric, 125, 3. Diakses dari http // www.ncbi.nlm.nih.gov/ pubmed/11331725

Zogara, A. U., Hadi, H., Arjuna, T. (2014). Riwayat Pemberian ASI Eksklusif dan MPASI Dini sebagai Prediktor Terjadinya Stunting pada Baduta di Kabupaten Timor Tengah Selatan, Nusa Tenggara Timur. Jurnal Gizi dan Dietetik Indonesia, 2(1), 53-62. Diakses dari http:// ejournal.almaata.ac.id/index.php/IJND/article/ view/ 